\title{
ANALISIS PELAKSANAAN REKOMENDASI OMBUDSMAN SEBAGAI INSTRUMEN PENGAWAS KEBIJAKAN PUBLIK
}

\author{
Imron Rizki A \\ Institut Agama Islam Negeri (IAIN) BONE \\ E-mail Korespondensi : imronrizki.91@gmail.com
}

\begin{abstract}
Abstrak
Ombudsman merupakan sebuah lembaga yang memiliki kewenangan melakukan pengawasan terhadap penyelenggaraan pelayanan publik yang diselenggarakan oleh penyelenggara negara dan pemerintahan termasuk yang diselenggarakan oleh Badan Usaha Milik Negara dan Badan Usaha Milik Daerah yang diberi tugas menyelenggarakan pelayanan publik. Ombudsman hadir untuk mewujudkan aparatur penyelenggara negara dan pemerintahan yang efektif dan efisien, jujur, bersih, terbuka serta bebas dari korupsi, kolusi, dan nepotisme. Dengan demikian Ombudsman diharapkan pula dapat membuat reformasi birokrasi yang baik sehingga keberadaannya benar-benar dapat dirasakan oleh masyarakat Indonesia. Diharapkan pula para penyelenggara negara dan pemerintahan memiliki kesadaran hukum yang baik untuk dapat mentaati rekomendasi yang dikeluarkan oleh Ombudsman.
\end{abstract}

Kata kunci : Ombudsman, Pelaksanaan, rekomendasi

\section{Pendahuluan}

Negara Indonesia telah mendeklarasikan diri sebagai negara hukum, hal ini tertuan didalam Pasal 1 ayat 3 Undang-undang Dasar Negara Republik Indonesia Tahun $1945^{1}$ Untuk memberikan jaminan perlindungan hukum bagi seluruh warga negara. Secara teoritis menurut Mochtar Kusumaatmaja dalam Irfan Fachrudin mangatakan "pengertian mendasar dari negara hukum adalah kekuasaan tumbuh pada hukum dan semua orang tunduk kepada hukum". Dengan dasar tersebutlah Indonesia secara perlahan menuju menjadi negara demokrasi, sejahtera dan berdaulat.

\footnotetext{
1 Pasal 1 ayat 3 Undang-undang Dasar Negara Republik Indonesia Tahun 1945

2 Irfan Fachrudin,2004, Pengawasan PeradilanAdministrasi Terhadap Tindakan Pemerintah, Alumni, Bandung. Hlm. 125
} 
Dalam upaya menuju negara yang demokrasi, sejahtera dan berdaulat maka tugas pemerintah dalam menyelenggarakan kepentingan umum menjadi sangat luas. Untuk itu diperlukan adanya suatu lembaga yang mampu membantu pemerintah untuk mengawasi dirinya sendiri dan para penyelenggara yang tergabung didalamnya, agar seluruh pemegang kebijakan publik harus didasarkan pada penyelenggaraan negara yang demokratis dalam rangka meningkatkan kesejahteraan, menciptakan keadilan, dan kepastian hukum bagi seluruh warga negara sebagaimana dimaksud dalam Undang-Undang Dasar Negara Republik Indonesia Tahun 1945.

Namun faktanya yang kita lihat sekarang ini, apa yang diharapkan dari para penyelenggara pemerintahan masih jauh dari harapan terutama dibidang pelayanan publik, seperti rendahnya kualitas pelayanan publik yang dilakukan oleh penyelenggara negara dan pemerintahan, tingginya tingkat penyalahgunaan wewenang dalam bentuk korupsi, kolusi dan nepotisme, birokrasi yang panjang dan/atau tidak jelas standar pelayanannya.

Didalam suatu negara yang berdaulat dibutuhkan suatu lembaga yang berfungsi sebagai pengawas pelayanan publik, karena tidak mungkin pemerintah mampu melakukan pengawasan terhadap dirinya sendiri. Pengawasan pelayanan yang dilakukan dan diselenggarakan oleh negara dan pemerintahan merupakan unsur penting dalam upaya menciptakan pemerintahan yang baik, bersih dan efisien serta sekaligus merupakan implementasi prinsip demokrasi yang perlu ditumbuhkembangkan dan diaplikasikan guna mencegah dan menghapuskan penyalahgunaan wewenang oleh aparatur penyelenggara negara dan pemerintahan.

Dari hal tersebut diatas maka negara mencoba untuk meresponnya dengan membuat suatu lembaga independent yang bersifat mandiri, dan tidak memiliki hubungan organik dengan lembaga negara dan instansi pemerintahan lainnya, serta dalam menjalankan tugas dan wewenangnya bebas dari campur tangan 
kekuasaan lainnya. Maka pada tanggal 10 Maret tahun 2000 dibentuklah Komisi Ombudsman Nasional melalui Keputusan Presiden Nomor 44 Tahun 2000. ${ }^{3}$

Adapun tujuan pembentukan Komisi Ombudsman Nasional tersebut, adalah untuk membantu menciptakan dan atau mengembangkan kondisi yang kondusif dalam melaksanakan pemberantasan Korupsi, Kolusi, dan Nepotisme melalui peran serta masyarakat. Selain itu, untuk meningkatkan perlindungan hakhak masyarakat agar memperoleh pelayanan umum, keadilan, dan kesejahteraan secara lebih baik. Untuk mewujudkan tujuan tersebut, Ombudsman Nasional diberi tugas pokok antara lain melakukan langkah-langkah untuk menindaklanjuti laporan atau informasi mengenai terjadinya penyimpangan oleh penyelenggaran negara dalam melaksanakan tugasnya maupun dalam memberikan pelayanan umum.

Bila kita lihat Keppres Nomor 44 Tahun 2000, setidaknya telah ada upaya untuk menciptakan dan atau mengembangkan kondisi yang kondusif dalam melaksanakan pemberantasan Korupsi, Kolusi, dan Nepotisme melalui peran serta masyarakat. Meningkatkan perlindungan hak-hak masyarakat agar memperoleh pelayanan umum, keadilan, dan kesejahteraan secara lebih baik. ${ }^{4}$ Sebagai lembaga yang mempunyai tugas mengawasi pelayan publik di Indonesia, lembaga pengawas tersebut harus mempunyai kedudukan dan dasar hukum yang kuat serta memiliki fungsi yang jelas. Untuk itu dalam perkembangannya, Komisi Ombudsman Nasional yang dibentuk berdasarkan Keppres Nomor 44 Tahun 2000 tersebut kemudian mengalami perubahan dengan dikeluarkannya Undang-Undang Nomor 37 Tahun 2008 tentang Ombudsman Republik Indonesia. Perubahan tersebut antara lain menyangkut nama, status kelembagaan, ruang lingkup kewenangannya serta beberapa hal yang substansial didalamnya dengan harapan mampu memperkuat kedudukan dan fungsi Ombudsman itu sendiri. Ombudsman Republik Indonesia adalah lembaga negara yang mempunyai kewenangan mengawasi penyelenggaraan pelayanan publik baik yang diselenggarakan oleh

\footnotetext{
${ }^{3}$ Asmara Galang.2012.Ombudsman Republik Indonesia Dalam Sistem Ketatanegaraan Republik Indonesia , hlm. 2

${ }^{4}$ Lihat Pasal 3 Keppres Nomor 44 Tahun 2000
} 
penyelenggara negara dan pemerintahan termasuk yang diselenggarakan oleh Badan Usaha Milik Negara, Badan Usaha Milik Daerah, dan Badan Hukum Milik Negara serta badan swasta atau perseorangan yang diberi tugas menyelenggarakan pelayanan publik tertentu yang sebagian atau seluruh dananya bersumber dari anggaran pendapatan dan belanja negara dan/atau anggaran pendapatan dan belanja daerah. ${ }^{5}$

Dengan lahirnya Undang-Undang Nomor 37 Tahun 2008 tentang Ombudsman Republik Indonesia juga menjadikan tujuan Ombudsman menjadi lebih luas dan jelas, yaitu ; (a). Mewujudkan negara hukum yang demokratis, adil, dan sejahtera; (b) Mendorong penyelenggaraan negara dan pemerintahan yang efektif dan efisien, jujur, terbuka, bersih, serta bebas dari korupsi, kolusi, dan nepotisme; (c) Meningkatkan mutu pelayanan negara di segala bidang agar setiap warga negara dan penduduk memperoleh keadilan, rasa aman, dan kesejahteraan yang semakin baik; (d) Membantu menciptakan dan meningkatkan upaya untuk pemberantasan dan pencegahan praktek-praktek Maladministrasi, diskriminasi, kolusi, korupsi, serta nepotisme; (e) Meningkatkan budaya hukum nasional, kesadaran hukum masyarakat, dan supremasi hukum yang berintikan kebenaran serta keadilan. ${ }^{6}$

Disisi lain, hal positif dari keluarkannya Undang-Undang Nomor 37 tahun 2008, Ombudsman dimungkinkan untuk dapat membuka kantor perwakilan di provinsi dan/atau kabupaten/kota. Pembentukan Perwakilan Ombudsman ini bertujuan memberikan kemudahan bagi masyarakat untuk mengakses pelayanan dari Ombudsman dalam rangka meningkatkan efisiensi dan efektivitas pengawasan untuk mewujudkan peningkatan kualitas pelayanan publik yang baik. ${ }^{7}$ Namun setelah 18 tahun Ombudsman berdiri, ada banyak kendala yang dihadapi, beberapa hal yang dihadapi adalah ketidakpopuleran Ombudsman dimata masyarakat Indonesia, sehingga menimbulkan sebuah pertanyaan

\footnotetext{
${ }^{5}$ Pasal 1 Ayat 1 Undang-Undang Nomor 37 tahun 2008

${ }^{6}$ Pasal 4 Undang-Undang Nomor 37 tahun 2008

7 Pasal 2 ayat (2) peraturan pemerintah republik indonesia nomor 21 tahun 2011 tentang pembentukan, susunan, dan tata kerja perwakilan ombudsman republik indonesia di daerah
} 
mendasar bahwa bagaimana mungkin lembaga ini bisa berjalan efektif jika eksistensi dan kehadirannya dimasyarakat tidak dikenal luas, lebih lanjut kendala yang dihadapi oleh Ombudsman adalah persoalan kekuatan dari produk yang dihasilkan oleh Ombudsman dalam hal ini rekomendasi Ombudsman, sebab produk yang dihasilkan oleh Ombudsman hanya sampai pada Rekomendasi, Rekomendasi Ombudsman yang dimaksud adalah kesimpulan, pendapat, dan saran yang disusun berdasarkan hasil investigasi Ombudsman, kepada atasan Terlapor untuk dilaksanakan dan/atau ditindaklanjuti dalam rangka peningkatan mutu penyelenggaraan administrasi pemerintahan yang baik. ${ }^{8}$ Ombudsman tidak memiliki kewenangan menuntut maupun menjatuhkan sanksi kepada Pejabat ataupun instansi penyelenggara negara yang dilaporkan, hal inilah yang menjadikan eksistensi Ombudsman lemah dimata masyarakat.

\section{Pembahasan}

\section{A. Pelaksanaan Rekomendasi Ombudsman}

Negara Indonesia yang merupakan salah satu negara demokratis hampir sama seperti negara demokrasi lainnya di dunia, yakni menganut sistem trias politica. Sistem trias politica ini membagi kekuasaan ke dalam legislatif, yudikatif dan eksekutif. Ombudsman tidak mempunyai yurisdiksi terhadap cabang kekuasaan legislatif dan yudikatif, namun mempunyai wewenang untuk melakukan investigasi atas keluhan masyarakat terhadap lembaga eksekutif. Secara umum lembaga ombudsman berhubungan dengan keluhan masyarakat akan adanya maladministrasi yang dilakukan oleh lembaga penyelenggara pemerintahan untuk melakukan penyelidikan secara objektif terhadap keluhankeluhan masyarakat mengenai administrasi pemerintahan. Seringkali pula Ombudsman mempunyai kewenangan untuk berinisiatif melakukan penyelidikan walaupun tanpa adanya pengaduan dari masyarakat, hal ini merupakan pengejawantahan dari paham yang dianut oleh Ombudsman Indonesia yaitu menganut sistem Ombudsman proaktif, hal ini dirasa penting dikarenakan agar

\footnotetext{
${ }^{8}$ Pasal 1 angka 7 Undang-Undang Republik Indonesia Nomor 37 Tahun 2008 Tentang Ombudsman Republik Indonesia
} 
Ombudsman selaku pengawas kebijakan publik dapat selalu mengawasi tindakan maladministrasi yang dilakukan oleh penyelenggara negara dan pemerintahan.

Sebelum kita mengetahui bagaimana pelaksanaan rekomendasi Ombudsman terlebih dahulu kita harus memahami apa yang dimaksud dengan rekomendasi Ombudsman itu sendiri. Rekomendasi disini diartikan sebagai saran (suggestion), Namun kadangkala dapat juga berarti nasihat. Hubungan rekomendasi dengan tugas dan wewenang Ombudsman adalah sebagai saran atau nasihat kepada pejabat pemerintah atau penyelenggara negara tentang apa yang harus dilakukan guna memperbaiki pelayanan yang dikeluhkan masyarakat, baik itu yang sifatnya kasus demi kasus maupun yang sifatnya sistemik. Sebab, rekomendasi Ombudsman berkaitan dengan tugasnya sebagai pengawas pelayanan publik yang dibentuk berdasarkan undang-undang untuk meningkatkan penyelenggaraan pemerintahan yang baik (good governance) serta menciptakan lingkungan yang kondusif untuk pelayanan berupa hukum yang adil, termasuk pemberantasan dan mencegah perilaku KKN. ${ }^{9}$

Ombudsman memberikan rekomendasi kepada instansi terlapor setelah melakukan pemeriksaan secara intensif dan mendapatkan temuan ataupun buktibukti terkait terjadinya maladministrasi. Rekomendasi yang dibuat oleh Ombudsman, sebagaimana telah diatur dalam undang-undang tentang Ombudsman, sekurang-kurangnya memuat: (1) Uraian singkat tentang laporan; (2) Uraian tentang hasil pemeriksaan; (3) Unsur-unsur maladministrasi yang terjadi; dan (4) Kesimpulan dan pendapat Ombudsman mengenali hal-hal yang perlu dilaksanakan Terlapor dan/atau atasan Terlapor. ${ }^{10}$

Lebih lanjut, rekomendasi tersebut disampaikan kepada Pelapor, Terlapor, dan atasan Terlapor dalam waktu paling lambat 14 (empat belas) hari terhitung sejak tanggal rekomendasi ditandatangani oleh Ketua Ombudsman. Kemudian,

\footnotetext{
9 Antonius Sujata dan RM Surachman, 2002, Ombudsman Indonesia di Tengah Ombudsman Internasional sebuah Antologi, Komisi Ombudsman Nasional, Jakarta. hlm. 202

${ }^{10}$ Pasal 37 ayat (2) Undang-Undang Republik Indonesia Nomor 37 Tahun 2008 Tentang Ombudsman Republik Indonesia
} 
atasan Terlapor wajib menyampaikan laporan kepada Ombudsman tentang pelaksanaan rekomendasi yang telah dilakukan disertai hasil pemeriksaannya dalam waktu paling lambat 60 (enam puluh) hari terhitung sejak tanggal diterimanya rekomendasi. Bilamana Terlapor dan atasan Terlapor tidak melaksanakan rekomendasi atau hanya melaksanakan sebagian rekomendasi dengan alasan yang tidak dapat diterima oleh Ombudsman, Ombudsman dapat mempublikasikan atasan Terlapor yang tidak melaksanakan rekomendasi dan menyampaikan laporan kepada Dewan Perwakilan Rakyat dan Presiden. Terlapor dan atasan Terlapor yang melanggar ketentuan sebagaimana dimaksud dalam Pasal 38 ayat (1), ayat (2), atau ayat (4) Undang-Undang Nomor 37 Tahun 2008 Tentang Ombudsman Republik Indonesia dikenai sanksi administrasi sesuai dengan ketentuan peraturan perundang-undangan.

Sebelum Ombudsman mengeluarkan rekomendasi terlebih dahulu dilakukan pemeriksaan atas laporan yang masuk (jika ada laporan dari masyarakat) setelah pemeriksaan dilakukan Ombudsman dapat menentukan hasil pemeriksaan substantif apakah Ombudsman tidak berwenang melanjutkan pemeriksaan ataukah Ombudsman berwenang melanjutkan pemeriksaan.

Dalam hal Ombudsman berwenang melanjutkan pemeriksaan sebagaimana dimaksud dalam Pasal 26 ayat (2) huruf b Undang-Undang Nomor 37 Tahun 2008 Tentang Ombudsman Republik Indonesia, Ombudsman dalam melakukan pemeriksaan dapat memanggil secara tertulis Terlapor, saksi, ahli, dan/atau penerjemah untuk dimintai keterangan, meminta penjelasan secara tertulis kepada Terlapor; dan/atau melakukan pemeriksaan lapangan. Dalam memeriksa Laporan, Ombudsman wajib berpedoman pada prinsip independen, nondiskriminasi, tidak memihak, dan tidak memungut biaya. ${ }^{11}$ Di pasal 30 UU No. 37 Tahun 2008 juga diatur bahwa Ombudsman dalam melakukan pemeriksaan wajib menjaga kerahasiaan, kecuali demi kepentingan umum.

${ }^{11}$ Pasal 29 ayat (1) Undang-Undang Republik Indonesia Nomor 37 Tahun 2008 Tentang Ombudsman Republik Indonesia 
Setelah menerima laporan kemudian melakukan pemeriksaan Ombudsman dapat mengeluarkan hasil pemeriksaan berupa : (a) menolak Laporan; atau (b) menerima Laporan dan memberikan Rekomendasi. ${ }^{12}$ Dalam hal pemeriksaan laporan Ketua, Wakil Ketua, dan anggota Ombudsman dilarang turut serta memeriksa suatu Laporan atau informasi yang mengandung atau dapat menimbulkan konflik kepentingan dengan dirinya. ${ }^{13}$

\section{B. Kendala-Kendala Dalam Pelaksanaan Rekomendasi Ombudsman.}

Berdasarkan hasil penelitian penulis melalui penulusuran pelaksanaan rekomendasi Ombudsman, baik dengan cara membaca dan atau mempelajari beberapa diteratur diberbagai buku, internet maupun artikel, maka penulis simpulkan bahwa ada beberapa kendala yang Ombudsman hadapi dalam pelaksanaan rekomendasi, diantaranya ialah: pertama rendahnya tingkat kesadaran pejabat penyelenggara negara dan pemerintahan dalam mentaati rekomendasi dari Ombudsman, hal ini disebabkan dari tidak jelasnya sanksi yang diberikan kepada penyelenggara negara dan pemerintahan yang menolak ataupun tidak mengindahkan rekomendasi yang dikeluarkan oleh Ombudsman, dalam Undang-Undang Nomor 37 Tahun 2008 Tentang Ombudsman Republik Indonesia disebutkan bahwa Terlapor dan atasan Terlapor yang tidak melaksanakan rekomendasi Ombudsman dikenai sanksi administrasi, disinilah kemudian menjadi penyebab mengapa penyelenggara negara tidak mematuhi rekomendasi Ombudsman, sebab bukan Ombudsman yang berhak memberikan sanksi administrasi yang dimaksud. Disisi lain penyebab tidak ditaatinya rekomendasi Ombudsman adalah acapkali terjadi perbedaan penafsiran antara Ombudsman dengan Terlapor dan/atau pimpinan terlapor (penyelenggara negara dan pemerintahan) dari hasil pemeriksaan yang dilakukan oleh Ombudsman.

Kedua, Ombudsman tidak sekaligus menjadi lembaga Eksekutorial, dalam artian Ombudsman hanya mampu memberikan rekomendasi yang hanya bersifat kesimpulan, pendapat, dan saran tanpa dapat melakukan eksekusi dari hasil

\footnotetext{
${ }^{12}$ Ibid Pasal 35

${ }^{13}$ Ibid Pasal 40
} 
pemeriksaan atau investigasi yang dilakukannya, yang mampu mengeksekusi rekomendasi dari ombudsman tersebut hanyala penyelenggara negara dan pemerintahan itu sendiri (Pejabat atau Instansi yang terkait). Ketiga, lemahnya aturan yang mengatur tentang pelaksanaan rekomendasi Ombudsman dan aturan mengenai rekomendasi Ombudsman yang tidak dipatuhi.

\section{PENUTUP}

\section{A. Kesimpulan}

Ombudsman merupakan lembaga negara yang bersifat mandiri dan tidak memiliki hubungan organik dengan lembaga negara dan instansi pemerintahan lainnya, serta dalam menjalankan tugas dan wewenangnya bebas dari campur tangan kekuasaan lainnya. ${ }^{14}$ Ombudsman dalam menjalankan tugas dan wewenangnya berasaskan pada kepatutan, keadilan, non-diskriminasi, tidak memihak, akuntabilitas, keseimbangan, keterbukaan dan kerahasiaan.

Pelaksanaan rekomendasi Ombudsman masih jauh dari harapan. sejauh ini masih banyak penyelenggara negara dan pemerintahan yang tidak mematuhi rekomendasi dari Ombudsman. Dan adapun kendala yang dihadapi ialah rendahnya tingkat kesadaran pejabat penyelenggara negara dan pemerintahan dalam menaati rekomendasi dari Ombudsman, Ombudsman tidak mampu menjadi eksekutor dalam pelaksanaan rekomendasi yang dikeluarkan, lemahnya aturan tentang pelaksanaan rekomendasi Ombudsman tersebut.

\section{B. Saran}

Saran dari penulis adalah a) Ombudsman harus intens melakukan sosialisasi agar tugas dan fungsinya dapat diketahui oleh masyarakat luas, b) perlu dibuat ketentuan yang lebih rinci mengatur mengenai sanksi apabila rekomendasi tidak dilaksanakan sehingga mampu mengangkat wibawah Ombudsman dimata masyarakat selaku lembaga pengawas kebijakan publik, c) Perlu dibuat payung

14 Pasal 2 Undang-Undang Republik Indonesia Nomor 37 Tahun 2008 Tentang Ombudsman Republik Indonesia 
hukum yang lebih kuat mengenai kedudukan dan fungsi serta pelaksanaan rekomendasi Ombudsman.

\section{DAFTAR PUSTAKA}

\section{Buku}

Antonius Sujata dan RM Surachman, 2002, Ombudsman Indonesia di Tengah Ombudsman Internasional sebuah Antologi, Komisi Ombudsman Nasional, Jakarta.

Asmara Galang, 2012, Ombudsman Republik Indonesia Dalam Sistem Ketatanegaraan Republik Indonesia, Laksbang Yustitia

Irfan Fachrudin, 2004, Pengawasan Peradilan Administrasi Terhadap Tindakan Pemerintah, Alumni, Bandung.

Jimly Asshiddiqie, 2012, Perkembangan dan Konsolidasi Lembaga Pasca Reformasi, Sinar Grafika, Jakarta.

Munir Fuady. 2011. Teori Negara Hukum Modern (Rechtstaat). Cet. ke-2. RefikaAditama: Bandung

Ni'matul Huda, 2005, Hukum Tata Negara Indonesia, Raja Grafindo Persada, Jakarta.

Ridwan HR, 2013, Hukum Administrasi Negara, Rajawali Pers, Yogyakarta.

\section{Peraturan Perundang-undangan}

Undang - Undang Dasar Negara Republik Indonesia Tahun 1945

Undang-Undang Nomor 37 Tahun 2008 Tentang Ombudsman Republik Indonesia (Lembaran Negara Republik Indonesia Tahun 2008 Nomor 139, Tambahan Lembaran Negara Republik Indonesia Nomor 4899)

Undang-Undang Nomor 25 Tahun 2009 Tentang Pelayanan Publik (Lembaran Negara Reublik Indonesia Tahun 2009 Nomor 112, Tambahan Lembaran Negara Republik Indonesia Nomor 5038).

Keputusan Presiden Nomor 44 Tahun 2000 tentang Komisi Ombudsman Nasional 